\title{
Sources and Variability of Petroleum Hydrocarbon Residues in Sediments of Chilika Lagoon, East Coast of India
}

\author{
Bita Mohanty ${ }^{1}$ Pradipta R. Muduli $^{1} \cdot$ Gregory Cooper $^{2} \cdot$ Saroja K. Barik $^{1}$. \\ Debasish Mahapatro $^{1} \cdot$ Alaya T. Behera $^{1} \cdot$ Ajit K. Pattnaik $^{1}$
}

Received: 8 December 2016 / Accepted: 1 March 2017

(C) Springer Science+Business Media New York 2017

\begin{abstract}
The spatio-temporal distribution and the controlling factors of petroleum hydrocarbons (PHCs) in sediments of Chilika lagoon was investigated. Samples were collected during three seasons and quantified using UVfluorescence spectroscopy. Concentrations of PHCs in surface sediments varies from 0.18 to $12.13 \mathrm{ppm}$ (mean $3.71 \pm 3.94 \mathrm{ppm})$. Compared to the lagoon, the monitoring stations adjacent to jetties with high boating activities tend to have higher PHC concentrations, suggesting that the contribution is likely to be from fossil fuel combustion and accidental seepage. The sediment organic matter (OM) of Chilika ranges from $0.26 \%$ to $6.23 \%$. PHC maintains a positive correlation with $\mathrm{OM}(p<0.05 ; \mathrm{f}=0.334)$, indicating the long term deposition of PHC as sediment OM. However, there is no significant relation between PHC and sediment texture, indicating its negligible control over PHC. The recorded PHC concentrations are below the threshold limit (70 ppm) as classified by United States (US) National Academy of Sciences (NAS) and also lower than those reported from similar ecosystems in India and overseas. Since the long term deposition and the bioaccumulation of PHC cannot be avoided, it is essential to monitor these parameters periodically.
\end{abstract}

Keywords Petroleum hydrocarbon - Surface sediment . UVF spectroscopy $\cdot$ Anthropogenic activity $\cdot$ Pollution

Pradipta R. Muduli

prmuduli.wrtc@gmail.com

1 Wetland Research and Training Center, Chilika Development Authority, Barkul, Khurda, Odisha 752030, India

2 Geography and Environment, University of Southampton, Highfield Campus, SO17 1BJ, Southampton, UK
Petroleum hydrocarbon (PHC) received special attention because of its toxic, carcinogenic and mutagenic properties (Lyla et al. 2012). Globally, many studies have been conducted on the distribution of PHC in water columns, sediments, and aquatic organisms (Chouksey et al. 2004; Li et al. 2010; Venkatachalapathy et al. 2010). When directly released into water through spills or leaks, certain PHC fractions evaporate, but some fractions float and may form thin films over the surface of the water (Mohanty et al. 2016). Heavier fractions accumulate in sediment, which may affect bottom-feeding fish and organisms (Venkatachalapathy et al. 2010). PHCs are complex mixtures of several compounds with varying molecular structure and composition. It contains a wide range of normal alkanes, unsaturated hydrocarbons, non-symmetric cyclic hydrocarbon and polycyclic aromatic hydrocarbons (Veerasingam et al. 2015). PHC is readily adsorbed onto particulate matter and ultimately incorporates itself into sediment which acts as a reservoir for hydrophobic contaminants. Investigation on the composition of PHC compounds in different estuarine sediments can provide information about their sources and diagenetic processes, whilst also reflect the extent of anthropogenic pressures on the environment (Medeiros et al. 2005). Monitoring of such organic pollutants can also warn of the potential bioaccumulation of contaminants in organisms which may ultimately be consumed by humans as food. To date, there has been limited investigation on the extent of PHC in Indian lagoon ecosystems. Venkatachalapathy et al. (2013), Lyla et al. (2012) and Veerasingam et al. (2010) have studied the distribution of PHC within Indian marine sediments. However, information regarding the PHC distribution in Indian wetlands remains relatively unexplored, emphasising the need for this study.

Chilika, a designated Ramsar site (Fig. 1), is the largest brackish water lagoon located along the east coast of 


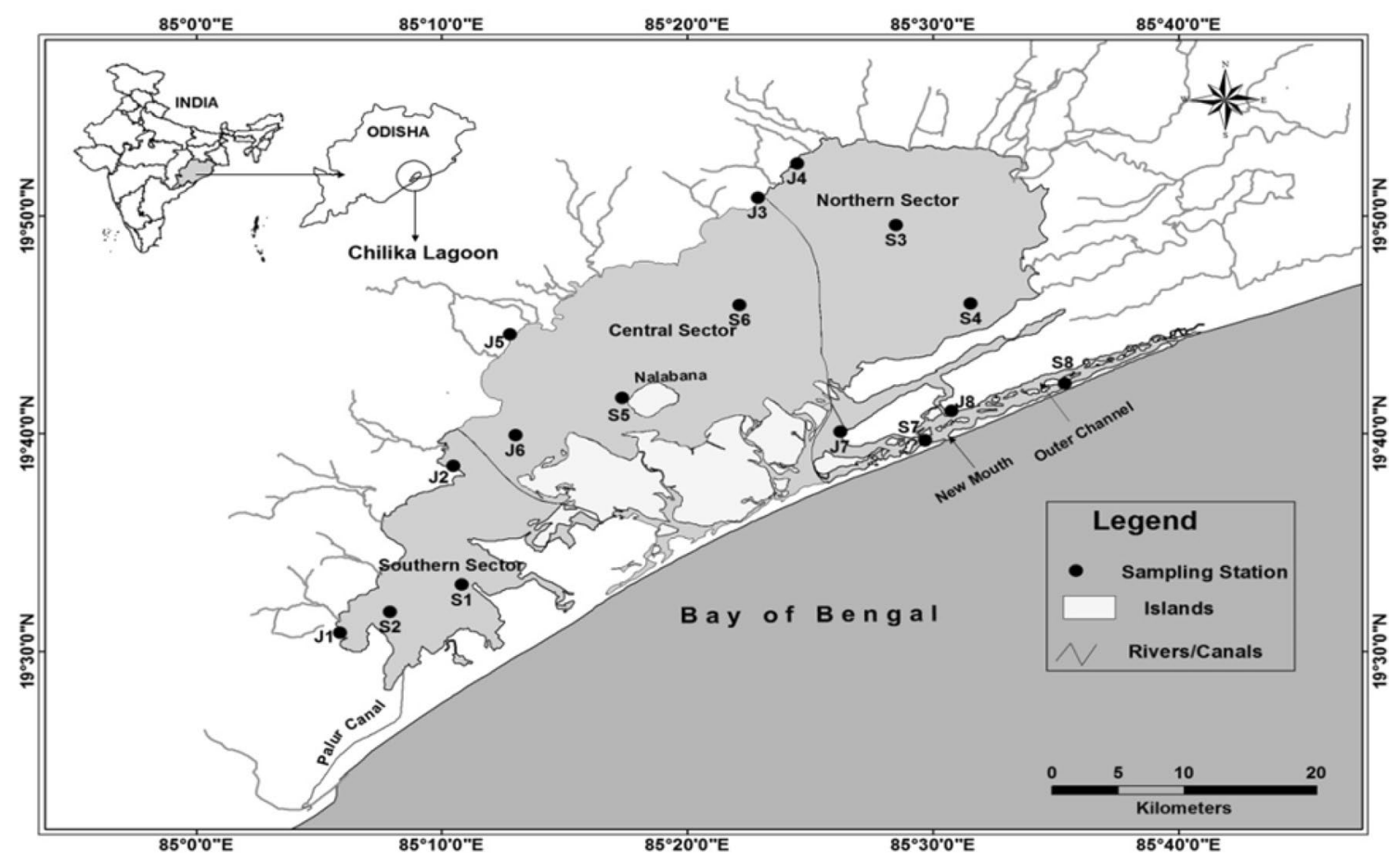

Fig. 1 Map showing the sixteen sampling locations across the Chilika lagoon

India. A total of 52 rivers and rivulets drain into the lagoon, out of which the northeast rivers contribute about $80 \%$ of the annual freshwater load. The mixing of freshwater from rivers and saline waters through the lagoon's mouth significantly influences the biogeochemistry and biodiversity of the lagoon (Muduli et al. 2012, 2013; Barik et al. 2017). Due to this complex salinity regime, the lagoon hosts a dynamic ecosystem that offers a vast array of biological diversity. The lagoon hosts a capture fishery, estimated to provide approximately 10,000 metric tons per annum (Mohapatara et al. 2007). Thus, it is estimated that fishery production from Chilika underpins 200,000 local livelihoods, resulting in approximately 6640 fishing boats active within the lagoon, of which 2342 are motorized and 3398 are non-motorized (Mohanty et al. 2016). The tourism sector is the major alternative livelihood activity; subsequently an additional 900 motorized boats are active in the tourism sector (Mohanty et al. 2016). During maintenance or operational activities of these boats, there might be chance of oil leakage or seepage from the boat engines. In addition, inflows from catchment areas and riverine input during monsoon season could also source the PHC in to the lagoon. Thus, a multitude of impacts from the various sources may be expected in the lagoon which can pose serious threats to the living biota. Considering the ecological and economical importance of the lagoon, this study investigates the following objectives: (i) evaluate the degree of sediment PHC contamination in comparison to the threshold limit of $70 \mathrm{ppm}$ as classified by US NAS (ii) understand the sources of PHC in the sediments and provide a base line information for future investigations across Chilika lagoon.

\section{Materials and Methods}

The sampling strategy aimed to cover the entire lagoon and jetties across all seasons. In total, 16 monitoring stations were selected, split into eight stations each of the major jetties and from the rest of the lagoon. These stations were uniformly selected to cover each of Chilika's four ecological regions, namely the southern, northern, central and outer channel sectors (Fig. 1). Sediment samples were collected during the premonsoon (May), monsoon (September) and postmonsoon (December) periods of 2014, in order to analyze petroleum hydrocarbon ( $\mathrm{PHC}$ ), organic matter $(\mathrm{OM})$ and sediment texture. A total of 48 samples (16 stations*three seasons) of estuarine surface sediment (top $5 \mathrm{~cm}$ ) were collected using a Van Veen grab (KC Denmark) and visible debris (any vegetation or animal shell etc.) were removed. Sediment samples were collected from the center part of the grab to avoid any metallic contamination and the sediment samples were wrapped in aluminum foil soon after collection. Afterwards, samples were stored in self-packing polyethylene bags at $-20^{\circ} \mathrm{C}$ until analysis. 
The collected sediments were then thawed, before $50 \mathrm{~g}$ of wet sample was soxhlet extracted for $2 \mathrm{~h}$ using a $\mathrm{KOH}-$ methanol mixture. Next, samples were extracted with n-hexane and dried over anhydrous $\mathrm{Na}_{2} \mathrm{SO}_{4}$. The concentrated extract was then separated on a silica-alumina column in order to measure the fluorescence of the total aromatic fraction (IOC-UNESCO 1982). PHC concentrations were determined using UV-Fluorescence (UVF) Spectroscopy (Hitachi 7000) and reported as wet weight (ww) basis of the sediment samples. Sediment fluorescence was measured using a Teflon-capped $1 \mathrm{~cm}$ silica fluorescence cell at an emission wavelength of $364 \mathrm{~nm}$ (excitation wavelength: $310 \mathrm{~nm}$ ); each sample was measured under identical instrumental conditions (IOC-UNESCO 1982). Chrysene was used as a standard reference to test precision and accuracy, and the data was expressed in terms of chrysene equivalents. Recovery percentage for spiked samples ranged from $94 \%$ to 98\%; precision was within $4 \%$. The Limit of detection $(3 \sigma)$ and limit of quantification $(10 \sigma)$ of this method was 0.1 and $0.43 \mathrm{ppm}$ respectively. All the estimates were conducted in triplicates with the average value reported. The surface sediment (upper $2 \mathrm{~cm}$ ) was used to analyze the total organic carbon percentage (TOC $\%$ ), estimated using the chromic acid oxidation method followed by back titration with ammonium ferrous sulfate (Walkley and Black 1934). OM concentration was computed from TOC\% using the multiplying factor of 1.724 (Trivedy and Goel 1984). Prior to texture analysis, the sediment samples were air dried, oxidized with $\mathrm{H}_{2} \mathrm{O}_{2}$ to remove organic matter and thoroughly homogenized by coning and quartering technique (Ingram 1971). One-hundred grams of the treated and dried sediment samples were taken for texture analysis [sand and mud (silt + clay) fractions] using a vibratory sieve shaker (RETSCH AS-200). The sand fraction was determined as the weight of sediment retained by the sieve $(125 \mu \mathrm{m}$ pore size); mud content equaled the weight/volume of sediment which passed through the sieve (Nazneen and Raju 2017). Two-way analysis of variance (ANOVA) at the $95 \%$ significance level ascertained whether significant differences exist between PHC concentrations with respect to spatial and temporal characteristics. Pearson's correlation coefficient analysis explored the interrelationship between sediment texture, OM and PHC. Nonmetric multidimensional scaling (nMDS) was performed after log transformation of the entire dataset in order to measure the spatial differences between the sampling stations by Euclidean distance. All statistical analyses were performed using IBM SPSS V.20 and PRIMER 6 software.

\section{Results and Discussion}

The mean concentration of PHC in the Chilika lagoon sediment varies widely from 0.39 to 10.97 ppm (Fig. 2). ANOVA shows that the PHC concentrations are significantly different between sampling sites $(p<0.001)$ but insignificantly different $(p>0.05)$ between seasons. Considering the average concentration of PHC in all three seasons, the highest recorded value corresponds to station $\mathrm{J} 4$ (12.13 ppm; Figs. 2, 3), which is located at a major fishing jetty. In comparison, the lowest concentration $(0.18 \mathrm{ppm})$ is observed at station S5 (Figs. 2, 3) which is close to the Nalabana bird sanctuary, where anthropogenic inputs are relatively limited as boat traffic and fishing activities are restricted and regulated by Chilika Wildlife Division (Dept. of Forest \& Environment, Govt. of Odisha, India). High concentrations near station $\mathrm{J} 4$ might be due to runoffs from the nearby township, as well as continuous or accidental fuel spills and engine leaks from boating activities (Table 1). In contrast, elevated levels of PHC at station J3 and J7 (Fig. 2) might be due to the high number of fishing boats and tourism activities. Similar to J4, the sources of PHC could be from oil spills, leaks from boat engines and operational discharge (Table 1). Previous studies from similar eco-hydrological environments also argue that major sources of PHC are attributed to fishing activities, tourism activities and untreated residues (Mohd Tahir et al. 1997; Li et al. 2010).

Textural classification reveals dominance of mud content in the surface sediments of the lagoon except for stations J2, J7, J8, S1, S2, S7 and S8 (Table 2). High mud percentages found at the northern and central parts of the lagoon could be due to the influx of suspended particulate matter (SPM) from the catchment which produces flocculation that settles on the lagoon bed (Patra et al. 2016). The higher sand contents at the outer channel (OC) and the southern region of the lagoon (Table 2) indicates a relatively high energy regime due to the tidal inlet and the Palur canal (Fig. 1), which consequently prevents sedimentation of fine grained particles (Veerasingam et al. 2011, 2015). The amount of $\mathrm{OM}$ in analyzed sediments is relatively moderate, ranging between $0.65 \%$ and $5.34 \%$ on average. The highest content of OM $(6.23 \%)$ was identified during the postmonsoon season at the J3 station (Table 2), which is located close to a fishing jetty. In contrast, the lowest $(0.26 \%)$ was concerned with the S7 station situated close to the lagoon inlet where sand dominated the sediment during the same season (Table 2). Correlation coefficient analysis reveals a significant positive relationship between $\mathrm{OM}$ and $\mathrm{PHC}(\mathrm{f}=0.334$; $p<0.05$ ), which was also observed in other ecosystems across India (Gomti river; Malik et al. 2004) and elsewhere (e.g. Chinese lakes; Wu et al. 2012). The positive relationship might be due to high Koc (organic carbon normalized 


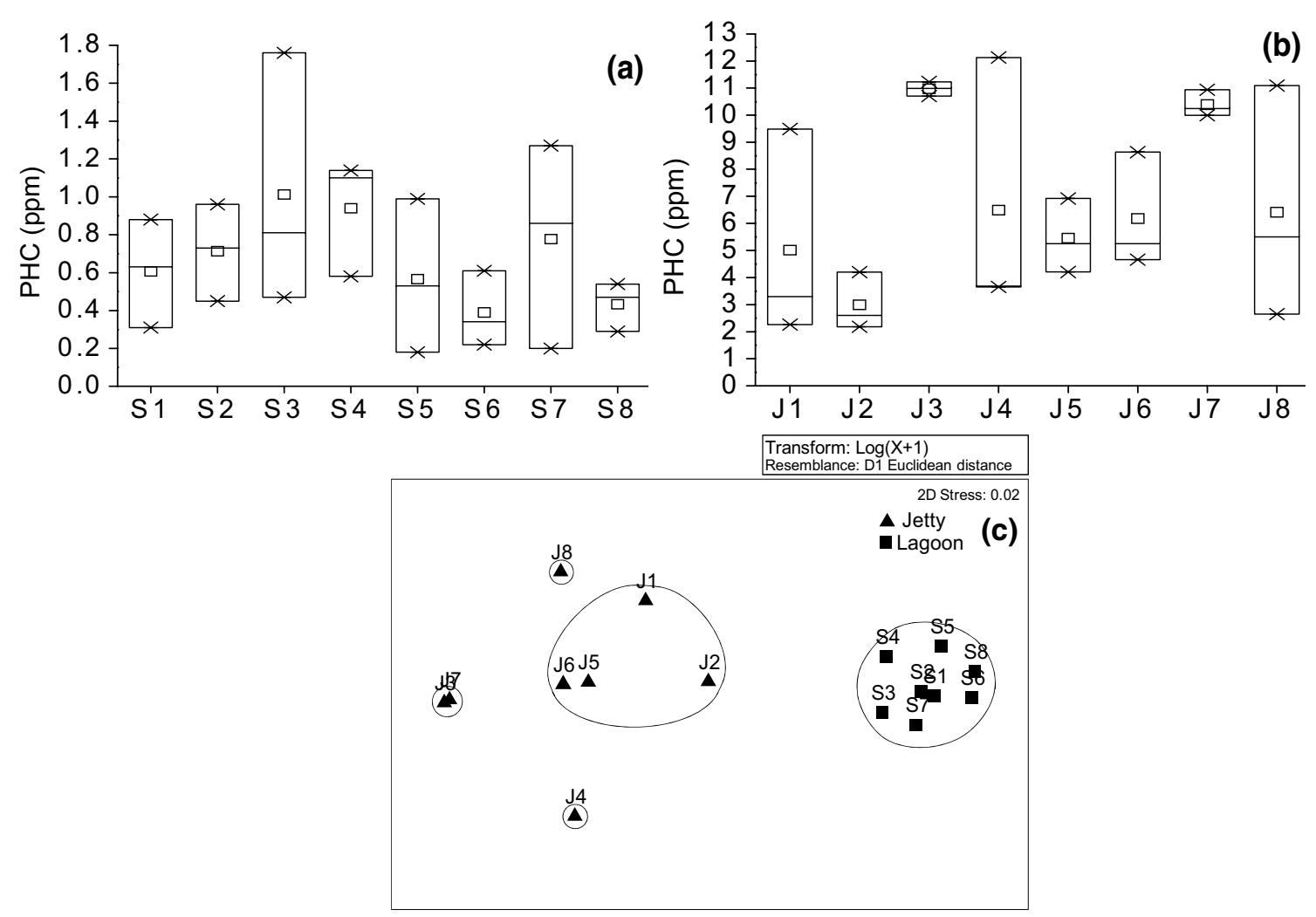

Fig. 2 Mean annual distribution of petroleum hydrocarbon concentrations in the sediment of a Chilika lagoon b surrounding jetties (inner boxaverage, asterisk-min/max, line inside box-median) and $\mathbf{c}$ nMDS plot showing similarities and grouping of sampling stations during 2014

Fig. 3 Seasonal distribution $( \pm \mathrm{SD})$ of petroleum hydrocarbon concentrations in a Chilika lagoon sediments and b surrounding jetties during 2014
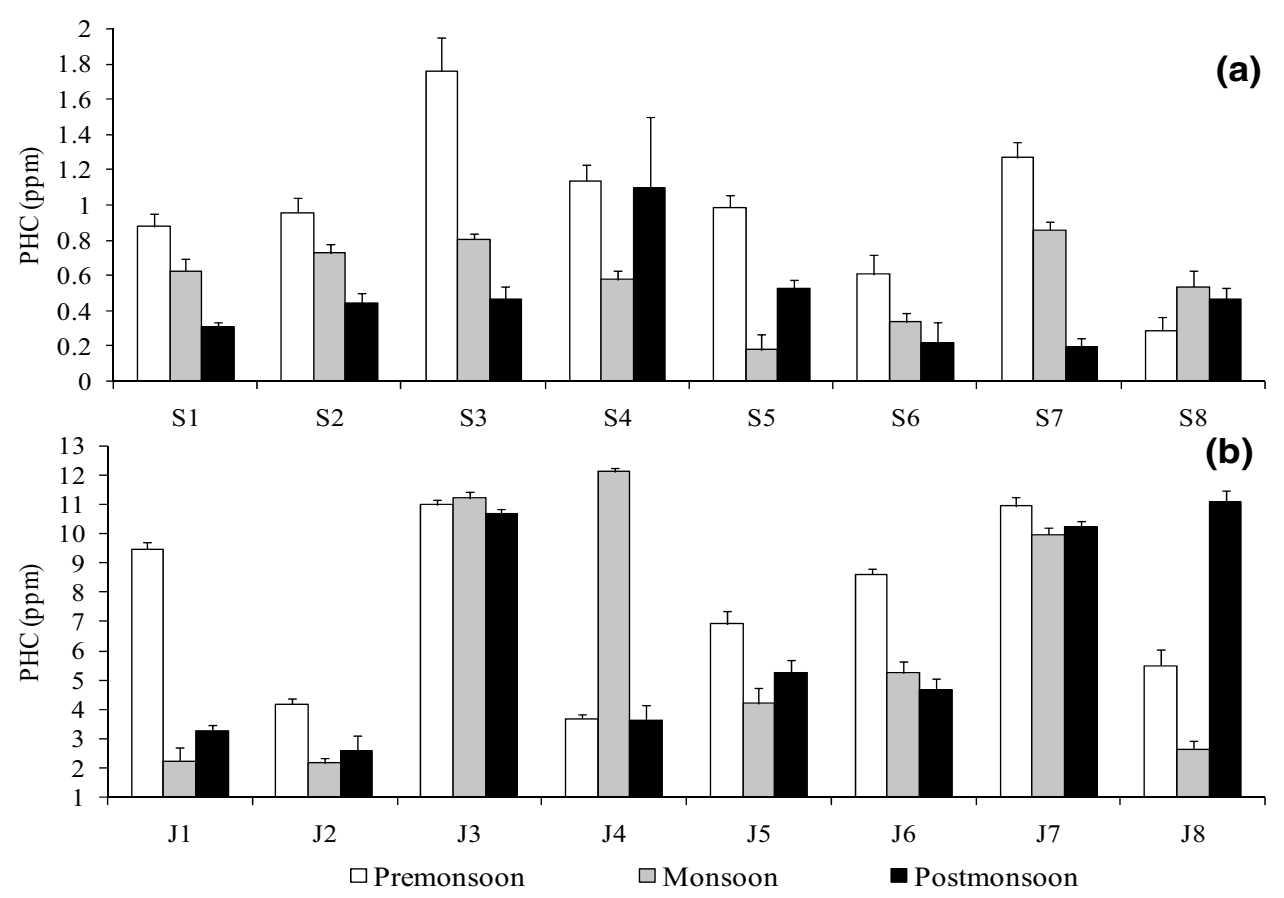

sorption coefficient) between $\mathrm{OM}$ and different compounds of PHC especially the polycyclic aromatic hydrocarbons (PAHs) (Wu et al. 2012). Under elevated loading of OM via anthropogenic sources, the sediments expected to be anoxic leading to low rate of microbial degradation and resulting in preservation of PHC residues (IOC-UNESCO 
Table 1 Possible sources/ routes of PHC into different locations of Chilika lagoon
Table 2 The results of sediment composition and organic matter for samples collected at various stations from Chilika lagoon

\begin{tabular}{llll}
\hline Station & Latitude & Longitude & Possible sources of PHC \\
\hline J1 & 19.51421 & 85.09737 & Boat traffic, catchment run off \\
J2 & 19.64231 & 85.17425 & Fishing jetty, boat traffic, catchment run off \\
J3 & 19.84772 & 85.38112 & Fishing jetty, boat traffic, catchment run off \\
J4 & 19.87400 & 85.40775 & Fishing jetty, boat traffic, catchment run off \\
J5 & 19.74294 & 85.21291 & Fishing jetty, boat traffic, catchment run off \\
J6 & 19.66547 & 85.21660 & Boat traffic \\
J7 & 19.66816 & 85.43715 & Boat traffic, catchment run off, tidal intrusion \\
J8 & 19.68429 & 85.51250 & Boat traffic, catchment run off, tidal intrusion \\
S1 & 19.55113 & 85.18002 & Boat traffic, catchment run off \\
S2 & 19.53042 & 85.13133 & Boat traffic, catchment run off \\
S3 & 19.82659 & 85.47483 & Boat traffic, riverine input \\
S4 & 19.76628 & 85.52532 & Boat traffic, riverine input \\
S5 & 19.69426 & 85.28911 & Boat traffic \\
S6 & 19.76538 & 85.36845 & Boat traffic \\
S7 & 19.66185 & 85.49467 & Boat traffic, tidal intrusion \\
S8 & 19.70506 & 85.58933 & Boat traffic, tidal intrusion \\
\hline
\end{tabular}

\begin{tabular}{|c|c|c|c|c|c|c|c|c|c|}
\hline \multirow[t]{2}{*}{ Station } & \multicolumn{3}{|c|}{ Premonsoon } & \multicolumn{3}{|l|}{ Monsoon } & \multicolumn{3}{|c|}{ Postmonsoon } \\
\hline & Sand $(\%)$ & Mud (\%) & $\mathrm{OM}(\%)$ & Sand (\%) & Mud (\%) & $\mathrm{OM}(\%)$ & Sand (\%) & Mud (\%) & $\mathrm{OM}(\%)$ \\
\hline $\mathrm{J} 1$ & 31.6 & 68.4 & 3.07 & 28 & 72 & 2.66 & 30.3 & 69.7 & 3.97 \\
\hline $\mathrm{J} 2$ & 72.7 & 28.3 & 1.08 & 67.2 & 22.8 & 2.96 & 64 & 36 & 3.37 \\
\hline $\mathrm{J} 3$ & 28.2 & 71.8 & 5.41 & 30.8 & 69.2 & 4.39 & 28.2 & 61.8 & 6.23 \\
\hline $\mathrm{J} 4$ & 7.9 & 92.1 & 3.11 & 39 & 61 & 4.44 & 40 & 60 & 3.83 \\
\hline J5 & 34.3 & 65.7 & 4.14 & 29 & 71 & 5.11 & 28.1 & 71.9 & 3.52 \\
\hline J6 & 49.2 & 50.8 & 4.29 & 22.8 & 77.2 & 2.13 & 46.6 & 53.4 & 3.92 \\
\hline $\mathrm{J} 7$ & 99.2 & 0.8 & 0.62 & 68.8 & 31.2 & 1.74 & 88 & 12 & 2.05 \\
\hline J8 & 90.8 & 9.2 & 1.38 & 81 & 19 & 3.09 & 86 & 14 & 1.64 \\
\hline S1 & 70 & 30 & 3.42 & 64.2 & 35.8 & 1.54 & 93.2 & 6.8 & 0.72 \\
\hline $\mathrm{S} 2$ & 68 & 32 & 2.79 & 69.2 & 30.8 & 1.64 & 74.8 & 25.2 & 3.3 \\
\hline S3 & 39 & 61 & 3.53 & 36 & 64 & 4.04 & 43.5 & 56.5 & 3.68 \\
\hline S4 & 37.6 & 62.4 & 2.93 & 38 & 62 & 1.84 & 34.8 & 65.2 & 2.51 \\
\hline S5 & 8.8 & 91.2 & 1.54 & 4 & 96 & 0.87 & 14.3 & 85.7 & 1.43 \\
\hline S6 & 34.2 & 65.8 & 4.19 & 31.4 & 68.6 & 2.91 & 30.5 & 69.5 & 2.81 \\
\hline S7 & 95.8 & 4.2 & 0.61 & 83.2 & 16.8 & 1.08 & 99.7 & 0.3 & 0.26 \\
\hline S8 & 82.5 & 17.5 & 0.72 & 75.6 & 24.4 & 0.74 & 73.2 & 26.8 & 0.52 \\
\hline
\end{tabular}

1982). Significant positive correlation of OM with sediment mud content $(\mathrm{f}=0.336 ; p<0.05)$ indicates that the source of OM could be from the sediment delivered to the lagoon from the surrounding catchments (Patra et al. 2016). A significant negative relationship of sand content and OM ( $\mathrm{f}=0.359 ; p<0.05)$ indicates that the sand dominated sediments in Chilika (such as the OC region) contains lower amount of organic compounds. This could be due to the less effective sediment-specific surface area, high porosity and permeability of the sediment (Burone et al. 2003). Statistically, an insignificant relationship was found between PHC and sediment texture, possibly due to the higher PHC concentrations observed in the jetties of the $\mathrm{OC}$ having predominantly sandy sediment texture.

In addition, the nMDS (Fig. 2) plot reveals a strong spatial heterogeneity between the lagoon stations as well as the jetty stations. Four jetty stations (J3, J4, J7 and J8) fall outside of the group because their PHC levels are significantly higher than the other sampling points. Certain sampling points, such as $\mathbf{J} 7$ and $\mathrm{J} 8$, are often crowded with tourist boats and leaching of PHC products from the boats suggests a reason for the higher concentrations. Similarly, stations such as J3 and J4 are adjacent to the major fish landing jetties, where the source of PHC is either from the 
maintenance of boats or oil seepage during boat operation. Thus, it is clearly illustrated that the jetties used for tourist activities and for the purpose of fish landing contributed a higher amount of PHC compounds into the bottom sediment. The higher concentrations of PHC at the jetty locations compared to the lagoon, are primarily attributed to fueling, boat maintenance and catchment runoff.

PHC concentrations obtained here are compared with previously reported values (Table 3 ). In the context of India, most previous studies have focused on coastal environments, such as the Visakhapatnam coast (Venkatachalapathy et al. 2013), Tamilnadu coast (Veerasingam et al. 2010), Chennai coast (Venkatachalapathy et al. 2010) and Bassein-Mumbai coast (Chouskey et al. 2004). The elevated levels of PHC in these coastal areas are attributed to marine based sources, in particular from shipping activities and the recent development of major industries. PHC concentrations of Chilika are evidently lower than those found for the Mandovi estuary, India (5.4-12.34 ppm; Veerasingam et al. 2015), Qua Iboe Estuary, Nigeria (18.01-210.23 ppm; Benson et al. 2008), Bizerte lagoon, Tunisia (0.05-19.5 ppm; Mzoughi et al. 2005), Ulhas estuary (2.0-40.8 ppm; Chouskey et al. 2004) and Patos Lagoon Estuary, Brazil (39-11,780 ppm; Zanardi et al. 1999) (Table 3). As classified by US National Academy of Sciences (NAS 1975), >70 ppm is considered as indication of pollution. In this regard, Food and Agriculture Organization (FAO) also classified the threshold as $<100 \mathrm{ppm}$ (FAO 1982). With reference to these thresholds, all studied locations of the lagoon are unpolluted. These threshold values has been used in several studies to identify the pollution status of the ecosystem (Ingole et al. 1995; Mohd Ali et al. 2013). Apart from these, no derived thresholds from regulatory agencies are available in literature for sediment PHC. However, considering the complex mixture of compounds (in PHC) recent studies has been focused on individual constituents of PHC in different environment (Kanzari et al. 2015; Devi et al. 2016). Overall, our study reveals that the PHC concentrations in the sediments of Chilika lagoon are within the threshold limit and are also lower than those reported for similar ecosystems in India and overseas. However, long term deposition may result in bioaccumulation by benthic feeders, including fish and shellfishes, which require periodic monitoring to formulate appropriate management strategies for the Chilika lagoon.

Acknowledgements The authors are thankful to World Bank assisted CDA-ICZMP component for financial support. We would like to acknowledge the contribution of Dr. S.K. Nag, CIFRI, Kolkata, India for providing necessary facilities in due course of work. Thanks are also to the staffs (A. Das and S.K. Panda) of CDA for their help in the field and laboratory during the study period and Mr. Bibhuti Dora, CDA for preparing the Chilika map using GIS.
Table 3 Comparison of PHC concentration in sediment of estuarine and marine coastal regions around the world reported from different authors

\begin{tabular}{lll}
\hline Location & PHC (ppm) & Source \\
\hline Chilika lagoon & $0.18-12.13$ & Present study \\
Mandovi estuary, India & $5.4-12.34$ & Veerasingam et al. (2015) \\
Visakhapatnam coast, India & $0.34-19.70$ & Venkatachalapathy et al. (2013) \\
Southeast coast, India & $1.58-4.07$ & Lyla et al. (2012) \\
Estuaries in Tamilnadu, India & $5.04-25.5$ & Veerasingam et al. (2011) \\
Tamilnadu coast, India & $1.48-4.23$ & Veerasingam et al. (2010) \\
Chennai coast, India & $1.88-39.7$ & Venkatachalapathy et al. (2010) \\
Qua Iboe Estuary, Nigeria & $18.01-210.23$ & Benson et al. (2008) \\
Gulf of Fos, France & $7.8-180$ & Mille et al. (2007) \\
Guanabara Bay, Brazil & $77-7751$ & Da Silva et al. (2007) \\
Jiaozhou Bay, China & $0.54-8.12$ & Wang et al. (2006) \\
Bizerte lagoon, Tunisia & $0.05-19.5$ & Mzoughi et al. (2005) \\
Bassein-Mumbai coast, India & $7.0-38.2$ & Chouksey et al. (2004) \\
Thane Creek, Mumbai coast, India & $7.6-42.8$ & Chouksey et al. (2004) \\
Dabhol-Ratnagiri coast & $0.9-107.7$ & Chouksey et al. (2004) \\
Ulhas estuary & $2.0-40.8$ & Chouksey et al. (2004) \\
Todos os Santos Bay, Brazil & $8-4163$ & Venturini and Tommasi (2004) \\
Fraser River Basin, Canada & $1.6-20.6$ & Yunker and Macdonald (2003) \\
Changjiang estuary, China & $2.2-11.82$ & Bouloubassi et al. (2001) \\
Patos Lagoon estuary, Brazil & $39-11,780$ & Zanardi et al. (1999) \\
\hline
\end{tabular}

Source: Veerasingam et al. $(2010,2011)$ 


\section{References}

Barik SK, Muduli PR, Mohanty B, Behera AT, Mallick S, Das A, Samal RN, Rastogi G, Pattnaik AK (2017) Spatio-temporal variability and the impact of Phailin on water quality of Chilika lagoon. Cont Shelf Res 136:39-56

Benson NU, Essien JP, Ebong GA, Williams AB (2008) Petroleum hydrocarbons and limiting nutrients in Macurareptantia, Procambarus clarkii and benthic sediment from Qua Iboe estuary, Nigeria. Environmentalist 28:275-282

Bouloubassi I, Fillaux J, Saliot A (2001) Hydrocarbons in surface sediments from the Changjiang (Yangtze River) estuary, East China Sea. Mar Pollut Bull 42(12):1335-1346

Burone L, Muniz P, Pires-vanin AMS, Rodrigues M (2003) Spatial distribution of organic matter in the surface sediments of Ubatuba Bay (Southeastern - Brazil). An Braz Acad Sci 75(1):77-90

Chouksey MK, Kadam AN, Zingde MD (2004) Petroleum hydrocarbon residues in the marine environment of Bassein - Mumbai. Mar Pollut Bull 49:637-647

Da Silva T, Azevedo D, Neto F (2007) Distribution of polycyclic aromatic hydrocarbons in surface sediments and waters from Guanabara Bay, Rio de Janeiro, Brazil. J Braz Chem Soc 18:628-637

Devi NL, Yadav IC, Shihua Q, Dan Y, Zhang G, Raha P (2016) Environmental carcinogenic polycyclic aromatic hydrocarbons in soil from Himalayas, India: implications for spatial distribution, sources apportionment and risk assessment. Chemosphere 144:493-502

Food and Agriculture Organisation (FAO) (1982) The Review of the Health of the Oceans. FAO/IMCO/UNESCO/WMO/WHO/ IAEA/UNEP Joint Group of Experts on Scientific Aspects of Marine Pollution (GESAMP)

Ingole SA, Kadam AN, Mayadeo MS, Dhadke PM (1995) Petroleum hydrocarbons in intertidal ecosystem along the Bombay coast. Ind J Mar Sci 24:116-118

Ingram RL (1971) Sieve analysis. In: Carver RE (ed) Procedures in sedimentary petrology. Wiley-Interscience, New York, pp 49-94

IOC-UNESCO (1982) The determination of petroleum hydrocarbons in sediments. Manuals guides No. 11:13-23

Kanzari F, Asia L, Syakti AD, Piram A, Malleret L, Mille G, Doumenq P (2015) Distribution and risk assessment of hydrocarbons (aliphatic and PAHs), polychlorinated biphenyls (PCBs), and pesticides in surface sediments from an agricultural river (Durance) and an industrialized urban lagoon (Berre lagoon), France. Environ Monit Assess 187:591

Li Y, Zhao Y, Peng S, Zhou Q, Ma LQ (2010) Temporal and spatial trends of total petroleum hydrocarbons in the seawater of Bohai Bay, China from 1996 to 2005. Mar Pollut Bull 60:238-243

Lyla S, Manokaran S, Khan A (2012) Petroleum hydrocarbon distribution in continental shelf region of southeast coast of India. Int J Sediment Res 27:73-83

Malik A, Singh KP, Mohan D, Patel DK (2004) Distribution of polycyclic aromatic hydrocarbons in Gomti river system, India. Bull Environ Contam Toxicol 72:1211-1218

Medeiros PM, Bicego MC, Castelao RM, Rosso CD, Fillmann G, Zamboni AJ (2005) Natural and anthropogenic hydrocarbon inputs to sediments of Patos Lagoon Estuary, Brazil. Environ Int 31:77-87

Mille G, Asia L, Guiliano M, Malleret L, Doumenq P (2007) Hydrocarbons in coastal sediments from the Mediterranean sea (Gulf of Fos area, France). Mar Pollut Bull 54(5):566-575

Mohanty B, Muduli PR, Behera AT, Mahapatro D, Barik SK, Nag SK, Samal RN, Pattnaik AK (2016) Assessment of petroleum hydrocarbon in a tropical brackish water lagoon: Chilika, India. Chem Ecol 32(7):653-668. doi:10.1080/02757540.2016.117752 1
Mohapatra A, Mohanty RK, Mohanty SK, Bhatta KS, Das NR (2007) Fisheries enhancement and biodiversity assessment of fish, prawn and mud crab in Chilika Lagoon after ecorestoration through hydrological intervention. Wetl Ecol Manag $15: 229-251$

Mohd Ali SA, Tair R, Yang SZ, Mohd Ali M (2013) Petroleum hydrocarbon in surface sediment from coastal area of Putatan and Papar, Sabah. Malays J Anal Sci 17(2):286-290

Muduli PR, Kanuri VV, Robin RS, Charan Kumar B, Patra S, Raman AV, Rao GN, Subramanian BR (2012) Spatio-temporal variation of $\mathrm{CO}_{2}$ emission from Chilika Lake, a tropical coastal lagoon, on the east coast of India. Estuar Coast Shelf Sci 113:305-313

Muduli PR, Kanuri VV, Robin RS, Charan Kumar B, Patra S, Raman AV, Rao GN, Subramanian BR (2013) Distribution of dissolved inorganic carbon and net ecosystem production in a tropical brackish water lagoon, India. Cont Shelf Res 64:75-87

Mzoughi N, Dachraoui M, Villeneuve JA (2005) Evaluation of aromatic hydrocarbons by spectrofluorometry in marine sediments and biological matrix: what reference should be considered? Comptes Rendus Chimie 8:97-102

NAS (1975) Petroleum in the marine environment. National Academy of Sciences, Washington, DC. pp 107

Nazneen S, Raju NJ (2017) Distribution and sources of carbon, nitrogen, phosphorus and biogenic silica in the sediments of Chilika Lagoon. J Earth Syst Sci 126(13). doi:10.1007/ s12040-016-0785-8

Patra S, Raman AV, Ganguly D, Robin RS, Muduli PR, Kanuri V, Subramanian BR (2016) Influence of suspended particulate matter on nutrient biogeochemistry of a tropical shallow lagoon, Chilika, India. Limnology. doi:10.1007/s10201-015-0475-2

Tahir NM, Abdullah AR, Shanmugam S (1997) Determination of total hydrocarbon concentration in coastal waters and sediments off the east coast of Peninsular Malaysia. Environ Geochem Health 19:67-71

Trivedy RK, Goel PK (1984) Chemical and biological methods for water pollution studies. Environmental Publications, Karad

Veerasingam S, Raja P, Venkatachalapathy R, Mohan R, Sutharsan P (2010) Distribution of petroleum hydrocarbon concentrations in coastal sediments along Tamil Nadu coast, India. Carpath J Earth Environ Sci 5:5-8

Veerasingam S, Venkatachalapathy R, Sudhakar S, Raja P, Rajeswari V (2011) Petroleum hydrocarbon concentrations in eight mollusc species along Tamilnadu coast, Bay of Bengal, India. J Environ Sci 23:1129-1134

Veerasingam S, Vethamony P, Mani Murali R, Babu MT (2015) Sources, vertical fluxes and accumulation of petroleum hydrocarbons in sediments from the Mandovi estuary, west coast of India. Int J Environ Res 9(1):179-186

Venkatachalapathy R, Veerasingam S, Ramkumar T (2010) Petroleum hydrocarbon concentrations in marine sediments along Chennai coast, Bay of Bengal, India. Bull Environ Contam Toxicol 85:397-401

Venkatachalapathy R, Rajeswari V, Basavaiah N, Balasubramanian T (2013) Environmental magnetic studies on surface sediments: a proxy for metal and hydrocarbon contamination. Int $\mathrm{J}$ Environ Sci Technol. doi:10.1007/s13762-013-0355-4

Venturini N, Tommasi LR (2004) Polycyclic aromatic hydrocarbons and changes in the trophic structure of polychaete assemblages in sediments of Todos os Santos Bay, Northeastern, Brazil. Mar Pollut Bull 48(1): 97-107

Walkley A, Black IA (1934) An examination of Degtjareff method for determining soil organic matter and a proposed modification of the chromic acid titration method. Soil Sci 37:29-37

Wang X C, Sun S, Ma HQ, Liu Y (2006) Sources and distribution of aliphatic and polyaromatic hydrocarbons in sediments of Jiaozhou Bay, Qingdao, China. Mar Pollut Bull 52(2):129-138 
Wu F, Xu L, Sun Y, Liao H, Zhao X, Guo J (2012) Exploring the relationship between polycyclic aromatic hydrocarbons and sedimentary organic carbon in three Chinese lakes. J Soil Sediment 12:774-783

Yunker MB, Macdonald RW (2003) Alkane and PAH depositional history, sources and fluxes in sediments from the Fraser River
Basin and Strait of Georgia, Canada. Org Geochem 34(10): 1429-1454

Zanardi E, Bicego MC, Miranda LB, Weber RR (1999) Distribution and origin of hydrocarbons in water and sediment in Sao Sebastiao, SP, Brazil. Mar Pollut Bull 38:261-267 